\title{
Relationship Between Business Competence and Business Survival of Culinary Business in Bandung
}

\author{
${ }^{1}$ ASEP KURNIAWAN, ${ }^{2}$ YUN YUN \\ 1,2Ekonomi dan Bisnis, Universitas Jenderal Achmad Yani, Cimahi, Jawa Barat \\ email: ${ }^{1}$ asep.kurniawan@lecture.unjani.ac.id; ${ }^{2}$ yunyun@lecture.unjani.ac.id
}

\begin{abstract}
SMEs (Small and Medium-size Enterprise) in Indonesian are only growing in terms of quantity and undeveloped in terms of quality, which causing a decrease in competitiveness. The solution is not through the provision of financial approach but can be in a form of an agency that knows about the market or those who can provide knowledge about the quality of the product. The objective of this study is to analyze the competence of small businesses and business survival of SMEs in culinary field of Bandung. The analytical method used in this research is Confirmatory Factor Analysis (CFA). CFA method is used to measuring the relationship between each indicator to explain the competence of small business and business sustainability. Indicator of entrepreneur competence and business survival can be explained by all indicator that researcher has been used. Small businesses of culinary in Bandung have a high category for the dimension of opportunity competency, organizing competency, strategy competency, social competency, and commitment competency. Nevertheless, there is still category of sufficient dimension, that is conceptual competency.
\end{abstract}

Keywords: Competence, Business Sustainability, SMEs

\section{Introduction}

ASEAN Economic Community (AEC) gives a distinct advantage to Small and Medium Enterprises (SMEs) in Indonesia. To that frame, MEA should be viewed as opportunities instead of obstacles. In Indonesia, SMEs have a strategic role and great contribution to the national economy by contributing $53.3 \%$ of total GDP (Gross Domestic Product) (Rianto, 2015). 99\% of the businesses in Indonesia are considered as SMEs. In Indonesian economy, SMEs are more resistant to a variety of threats, as when economic crisis occurred then SMEs were capable to survive and keep growing. The presence of SMEs in Indonesian economy is able to contribute to the country and increase labor utilization. In addition, SMEs can improve the gross domestic product (GDP), add more income for financial state and local budgets from taxes payment, and able to develop the business.

The products of SMEs will experience the consequences of the opening of ASEAN market. The SMEs which have already prepared themselves for this event will pleasurably welcoming the implementation of AEC because it will make the regional market easier to develop (Sutopo,2016).

Unfortunately, SMEs only increase in terms of quantity and not quality, which causing low competitiveness. In addition, the tendency of SMEs financial problems are also considered as the main obstacle of developing. There are three main problems of SMEs: there is no market guarantee, the inability to meet the quality, and certainty of production. Those problems cannot only be solved by providing financial approach but can also be done through an agency that knows about the market or those who can provide knowledge about the quality of the products of small businesses (Sakur, 2011)

SMEs have the ability to increase the income of small communities of low education level and limited capital by giving a

Received: December 04, 2017, Revision: March 19, 2018, Accepted: June 04, 2018

Print ISSN: 0215-8175; Online ISSN: 2303-2499. DOI: http://dx.doi.org/10.29313/mimbar.v34i1.3255.147-157

Accredited B based on the decree No.040/P/2014, valid on February, 18, 2014 until February, 18, 2019. Indexed by DOAJ, Sinta, IPI 
chance of employment and equal distribution of development outcomes. In the era of economic globalization and liberalization, SMEs contribute greatly to the development of national economy. Small and medium industries need to improve their competencies in order to maintain business continuity and enhance product competitiveness.

Bandung Raya (Cimahi, Bandung, Bandung Regency and Bandung Barat Regency) have many attractive tourist areas, beautiful natural scenes, and culinary tourism spots as the characteristics of the tourism area of Bandung Raya. The continued development of the culinary industry in Bandung area has increased the competition in the culinary field. In culinary field, quality becomes the main thing. Small businesses of culinary should be able to maintain the quality of its culinary products in order to continue their businesses and improving the competence of small businesses in the culinary field of Bandung Raya.

Bandung Raya is a tourist destination in West Java with one of the businesses supporting tourism in the area is culinary business. The rapid growth of culinary business in Bandung Raya makes the competition tougher. Entrepreneurs who do business in this field should have a good competence in culinary field.

The small businesses of culinary field should improve its competence in managing and determining the business strategy and the concept of culinary. The high opportunities in culinary field should be smartly utilized by small businesses entrepreneurs of culinary to develop their businesses. There are a lot of constraints in the nature of competences of the small businesses, one of which is the poor ability of managerial and decision making which makes the business stagnant.

Study by Kurniawan, et al (2016) which conducted a research in Cimahi and Bandung, state that small businesses of culinary are still lacking of competencies in organizing, making strategy, and conceptual. Those shortages may hamper the continuity of small businesses of culinary in Cimahi and Bandung. The small businesses of culinary should be able to improve their business competence in order to maintain the continuity of their business, especially since the competition is raising. To continue to exist in the competition and in an effort to increase market share, small businesses need to raise the culinary field entrepreneurial competence.
Kurniawan, et al (2014) also states that many SMEs have difficulty in running their business. Similarly, such constraints are also experienced by food industry. According to data from Badan Pusat Statistik (BPS) (2010), 745,824 businesses (34.96 percent, ) in food industry experienced their greatest difficultie scovering capital difficulty of 255,793 businesses, materials difficulty of 206,309 businesses and marketing difficulty of 146,185 businesses.

Objective to be achieved from this study is to analyze the competence and longevity of small businesses of culinary in Bandung Raya. The results are expected to provide answers and can be used as solutions to the problems occurred in the competence and continuity/ sustainability of small businesses.

\section{Research Methods}

According to the level of explanation, the study was classified into descriptive and a ssociative. Sugiyono (2017) explains about associative descriptive research: "A descriptive research method is done to find out independent variable load, either on one or more variables (independent variable) with out creating variable of relationship in itself and seek relationship with other variables." The definition of associative approach is also expressed also by Sugiyono (2017) as a formulation of a research problem that asks for a relationship between two or more variables.

The focus of this study was to determine the relationship of small businesses competence to the business continuity in culinary field in the area of Bandung Raya. The object of research that will be examined in this study is variables of entrepreneurial competence and survival efforts.

The population in this study are small businesses of culinary field in Bandung Raya (Bandung, Cimahi, Bandung Regency, and West Bandung Regency) with unknown population data. Therefore, this research uses judgment method to determine number of samples and managed to get 100 respondents as samples. The sampling technique is done rand omly, so that every member of the population has an equal chance to be selected as a sample. Random sampling is a probability sampling to select samples that meet the criteria of the researcher (stratified random sampling). 
The data collection techniques used in this research are as follows: A field study (field research) as the primary data collection which is done by conducting a review directly to the companies concerned with activities that include: (1) The interview that conducted with small businesses in Cimahi, Bandung, Bandung Regency, West Bandung Regency (2) Observation directly to the object being studied; (3) questionnaire, by providing a set of questions or a written statement to the respondent or the informant of small businesses in Cimahi, Bandung, Bandung Regency and West Bandung.

This research using categorization to explain answers from respondents.

Table1

Categorization of Opportunity Competency, Strategic Competency, Commitment Competency

\begin{tabular}{|l|l|l|}
\hline \multirow{2}{*}{ Category } & \multicolumn{2}{|l|}{ Score } \\
\cline { 2 - 3 } & From & To \\
\hline Very Low & 600 & 1080 \\
Low & 1080 & 1560 \\
\hline Enough & 1560 & 2040 \\
\hline High & 2040 & 2520 \\
\hline Very High & 2520 & 3000 \\
\hline
\end{tabular}

Table 2

Categorization of Organizing Competency, Social Competency, and Conceptual Competency

\begin{tabular}{lll}
\hline Category & \multicolumn{2}{l}{ Score } \\
\cline { 2 - 3 } & From & To \\
\hline Very Low & 500 & 900 \\
Low & 901 & 1300 \\
Enough & 1301 & 1700 \\
High & 1701 & 2100 \\
Very Low & 2101 & 2500 \\
\hline
\end{tabular}

Table 3

Categorization of Survival

\begin{tabular}{|l|l|l|}
\hline \multirow{2}{*}{ Category } & Score \\
\cline { 2 - 3 } & From & To \\
\hline Very Low & 300 & 540 \\
\hline Low & 543 & 780 \\
\hline Enough & 783 & 1020 \\
\hline High & 1023 & 1260 \\
\hline Very High & 1263 & 1500 \\
\hline
\end{tabular}

Table 4

Categorization of Going Concern and Empirical Facts

\begin{tabular}{|l|l|l|}
\hline \multirow{2}{*}{ Category } & \multicolumn{2}{|l|}{ Score } \\
\cline { 2 - 3 } & From & To \\
\hline Very Low & 400 & 720 \\
\hline Low & 724 & 1040 \\
\hline Enough & 1044 & 1360 \\
\hline High & 1364 & 1680 \\
\hline Very High & 1684 & 2000 \\
\hline
\end{tabular}

Table 5

Categorization of Entrepreneur Competence

\begin{tabular}{|c|c|c|}
\hline & Score & \\
\hline Category & From & To \\
\hline Very Low & 3300 & 5940 \\
\hline Low & 5940 & 8580 \\
\hline Enough & 8580 & 11220 \\
\hline High & 11220 & 13860 \\
\hline Very High & 13860 & 16500 \\
\hline
\end{tabular}

Table 6

Categorization of Business Survival

\begin{tabular}{|l|l|l|}
\hline \multirow{2}{*}{ Category } & \multicolumn{2}{|l|}{ Score } \\
\cline { 2 - 3 } & From & To \\
\hline Very Low & 1000 & 1800 \\
\hline Low & 1810 & 2600 \\
\hline Enough & 2610 & 3400 \\
\hline High & 3410 & 4200 \\
\hline Very High & 4210 & 5000 \\
\hline
\end{tabular}

Important step in the framework of data collection activities is to conduct a test on the instruments (gauges) which will be used. Testing activities of research instruments include two things, namely the validity and reliability test

To answer the question of the relationship of entrepreneurial competence variable with continuity of culinary business, confirmatory factor analysis is used with two levels where the tool can determine indicators of entrepreneur competence and business survival. From the picture above, there are two latent variables namely entrepreneurial competency and continuity of the business. Entrepreneurs variables measured by six indicators and continuity variables measured by three indicator. The equation of the image is as figure 1. 


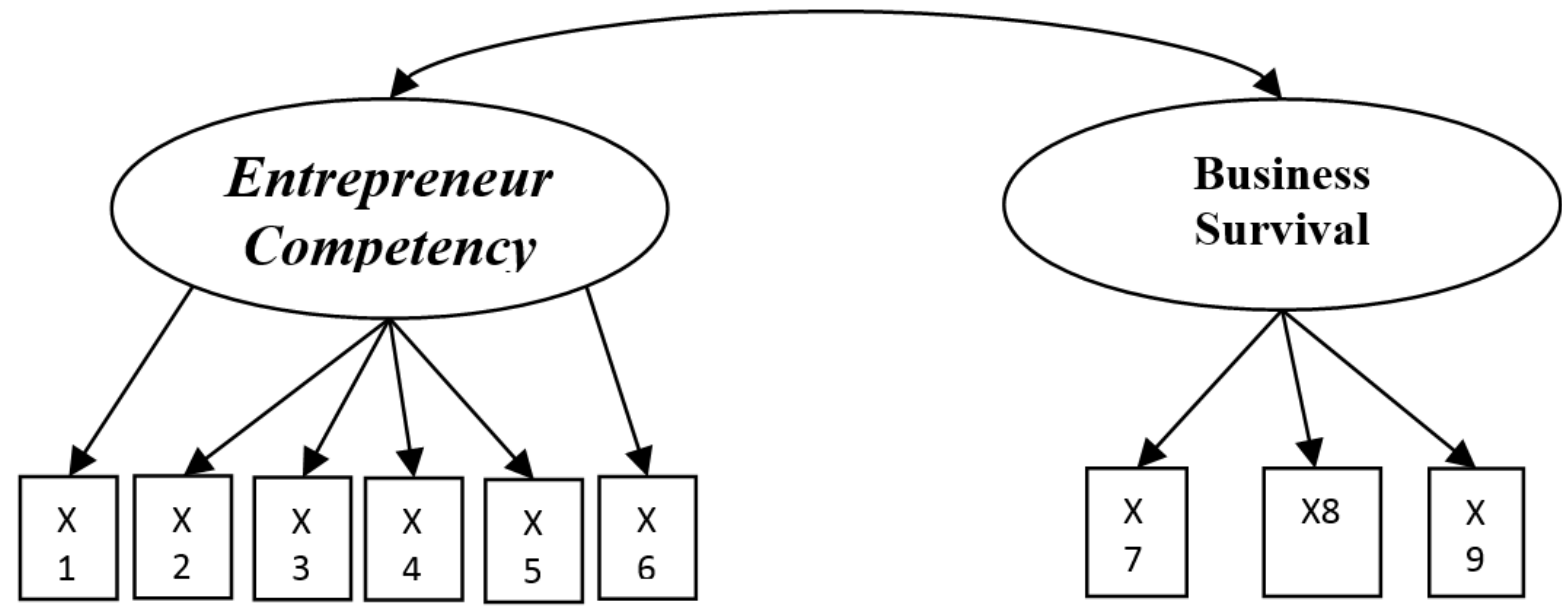

Figure 1. Confirmatory Factor Analysis

$$
\begin{aligned}
& X 1=\beta 1 \square+\mathrm{e} 1 \\
& X 2=\beta 2 \square+\mathrm{e} 2 \\
& \mathrm{X} 3=\beta 3 \square+\mathrm{e} 3 \\
& \mathrm{X} 4=\beta 4 \square+\mathrm{e} 4 \\
& \mathrm{X} 5=\beta 5 \square+\mathrm{e} 5 \\
& \mathrm{X} 6=\beta 6 \square+\mathrm{e} 6 \\
& \mathrm{X} 7=\beta 7 \square+\mathrm{e} 7 \\
& \mathrm{X} 8=\beta 8 \square+\mathrm{e} 8 \\
& \mathrm{X} 9=\beta_{9} \square+\mathrm{e} 9
\end{aligned}
$$

\section{Definition of Entrepreneurship Competency}

Competence is the main characteristic of most successful people in the organization or profession that helps them become very successful (Kessler: 2008). This statement is reinforced by Noe (2006) who states that competence is an aspect of a person's ability which includes knowledge, skills, attitudes, values or personal characteristics that allow workers to achieve success in completing their work through the achievement of results. Definition of competence was also delivered by Rimsky (2008) who said that in general the system of competence used by company consists of knowledge, skills, and behavior (attitude), which are applicable to human resources in achieving organizational goals of the company.

While Spencer and Spencer in Kaur (2013) explains that the competency as an underlying characteristic of an individual which causally related to criteria on referenced effective and/or superior performance in a job or situation. Furthermore, Dimitriades (2007) states that individuals who believe the purpose of the work associated with the organization tend to think of using the free time to focus on their job and search for better ways of working, and for individuals who feel they have the competence inclined to help other colleagues.

Small business of culinary needs entrepre neurial competence. Kaur and Bains (2013) state that competence of entrepren eurship/entrepreneurial competency can be defined as the individual characteristics. An entrepreneur is a person who undertakes the risk of gaining profit in the business venture. The notion explains that entrepreneurial competence as individual characteristics. The entrepreneur is the person who takes over the risk to benefit in the business undertaken.

\section{Characteristics of Entrepreneurial}

Entrepreneurship is a purposeful behavioral adaptation launched for initiating, promoting and maintaining economic activities for the production and mobilization of monetary resources (Khalid and Bhatti: 2015). Entrepreneurship is an adaptation of purposeful behavior that aims to initiate, promote and manage economic activities for the production and mobilization of financial resources.

According to Sastra in Sumual (2015), there are three kinds of competencies: core competencies, managerial competencies and functional competencies. Entrepreneurial skills includes openness, freedom, broad view, oriented to the future, plans, beliefs, aware and respectful of others, and other people's opinions. In achieving success, an entrepreneur has certain characteristics as well. Zimmerer and Scarborough (2005) quote from the "Entrepreneurship and Small Enterprise Development Report" suggested several 
successful entrepreneurial characteristics: 1) proactive, namely the initiative and firmly (assertive); 2) achievement-oriented, which is reflected in the views and act (sees and acts) against the odds, orientation efficiency, prioritizing the quality of work, planning and prioritizing monitoring; 3 ) a commitment to others, for example in organizing contacts and business relationships.

The entrepreneurial competencies consist of: the opportunity competency, relationship competency, conceptual competency, organizing competency, strategic competency, and commitment competency (Man, 2003). Thus, indicators of entrepreneurial competencies that serve as the measure in this research are opportunity competency, relationship competency, conceptual competency, organizing competency, strategic competency, and commitment competency. Six formers indicators will be used as a small business competence variable of culinary field in the area of Bandung Raya.

\section{Business Survival}

Business survival is a strategic issue for any business organization. Banbury (1995) states permanence context meaning business continuity in the existing organization of a relevant market it serves. The measures used include the duration and chances of survival.

There are at least three main reasons why a business needs to be in a permanence of entrepreneurial performance criteria. First, survival is a minimum size and a prerequisite for the success of the company's business performance indicators such as growth, profitability, market share and others. As an illustration, how companies can grow if they do not survive? Second, the principle of "going concern" in business accounting express primarily a business organization founded with the intent to live forever (Kieso: 2010). Criteria of survival, going concern and empirical facts will establish continuity of small businesses in the culinary field Bandung Raya.

\section{Preliminary Study on Business Competence and Continuity}

Few studies pointed out the link between the continuity of the business through entrepreneurial competencies. The study of Erävala, et, al (2014) stated that competency approach is divided into four perspectives of individual's viewpoint, entrepreneurial perspective, organizational side, and network perspective. Referring to the results of research, both internal competence and network competence are needed to survive in a crisis situation.

Research from Okpara (2011) showed problems faced by SMEs in Africa, namely the administration, operation, strategic and problems from the outside. The ability of small businesses to survive and grow their business in an entrepreneurial influenced by several factors, such as creativity and innovation. Furthermore, Sya'roni (2014) states in his research that in entrepreneurship requires self-knowledge, practical knowledge, search skills, computation skills, communication skills.

According to Kurniawan and Dwiana (2011), concept of competence is often used to reflect a person's ability in specific areas. Opinions mentioned above can be considered that competence consists of several aspects which consist of number of characteristics

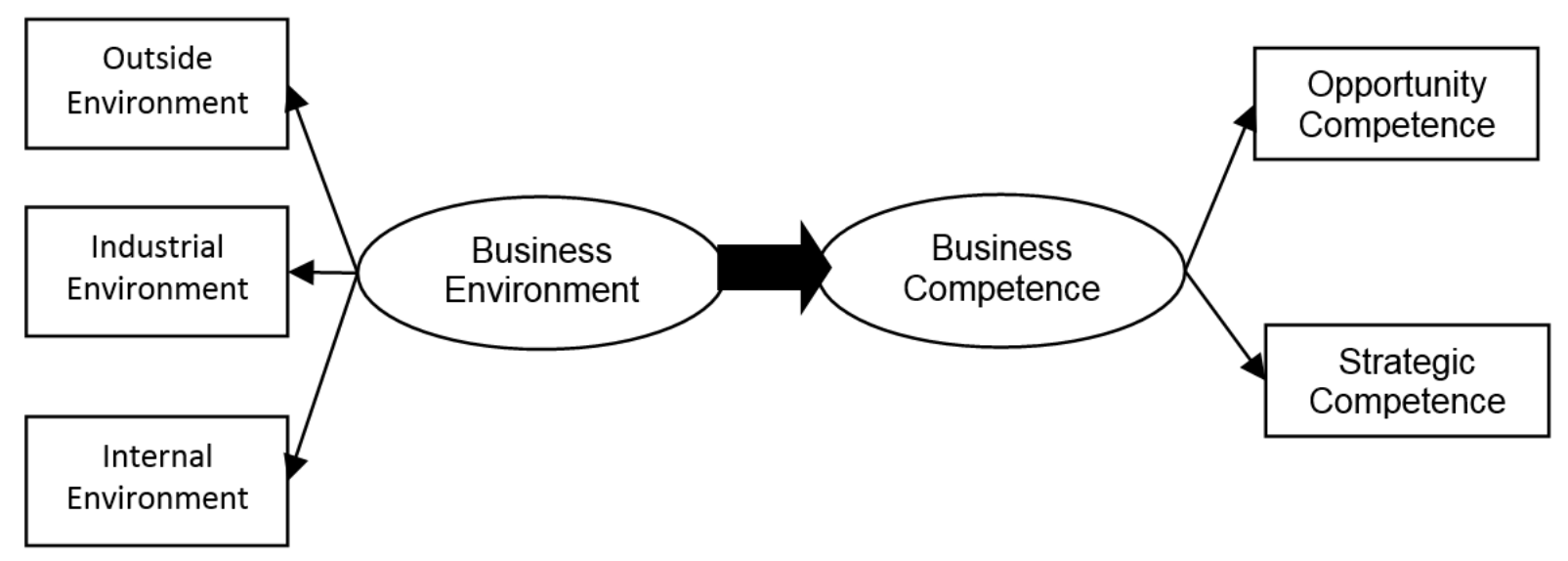

Figure 2: Analysis of Environmental Changes In Business Competence 
that have significance as an important factor of an individual and become part of one's personality, and can predict behavior that appears on the circumstances or a specific job. Competence is actually able to predict whether someone is behaving appropriately or not in his job.
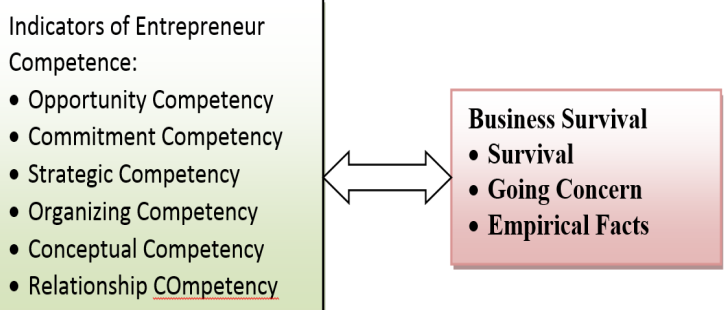

Figure 3. Paradigm Research of Entrepreneurship Competency Relationship with the Business Survival

\section{Profile of Respondents of Small Busi- ness Communities in Bandung Raya}

This study took 150 respondents from Bandung Raya (Bandung, Cimahi, Bandung Regency, and Bandung Barat Regency). Profile of respondents that was asked, among others, are years of business' establishment, workforce, and turnover per day.

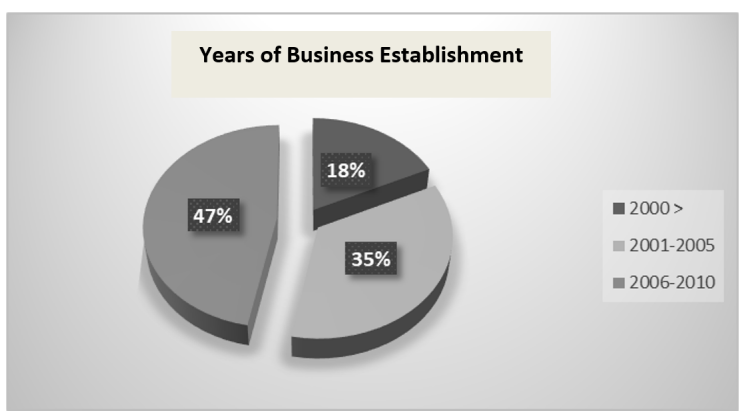

Figure 4. Year of Established

Source: Questionnaire, reprocessed in 2016

Based on the picture above, the majority of respondents are small businesses of culinary field that opened between 2006 and 2010. There are also businesses established from the year of $2001-2005$, and the year 2000 . The division of year for the respondent is quite even.

Next is the profile of the workforce working in the field of culinary business. The results are presented in the figure 5.

Based on the picture 6 , there is a quite uneven distribution of the number of workers of respondents. With a limited number of workers up to 4 people, there is $27 \%$ of small businesses that have a workforce of 4 people, 3 people of $33 \%$, and the most workers' number is 18 . The remaining two people who do not have the manpower is $1 \%$.

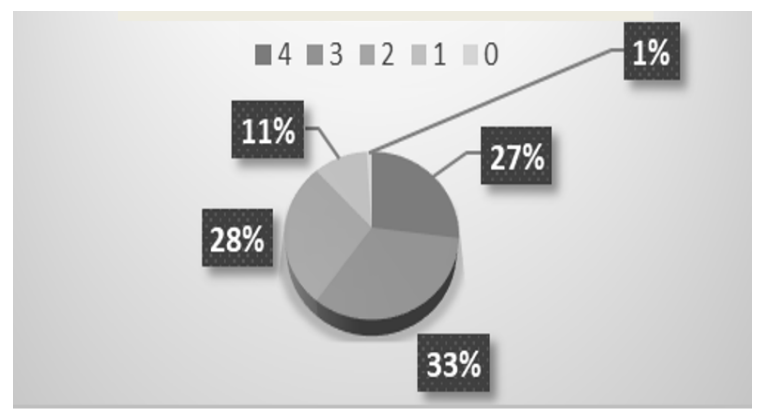

Figure 5 Number of Workers

Source: Questionnaire, reprocessed in 2017

Subsequently, it will discuss the turnover per day which described in the figure 6 :

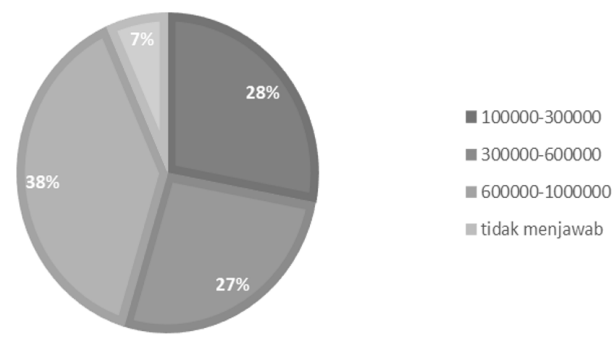

Figure 6 Turnover per day

Source: Questionnaire, reprocessed in 2017

The picture above shows that $38 \%$ of small businesses obtain daily turnover of between Rp 600,000 - Rp 1,000,000; A very small portion of small entrepreneurs responded to get a daily turnover of $\mathrm{Rp}$. 300,000 - Rp. 600.00; and 27\%.gained a turnover of between Rp 100,000 - Rp 300,000 .

\section{Respondents' Perception on Small Business Agent Competence of Culi- nary in Bandung. \\ Opportunity Competencies (Ability to Recognize Opportunities)}

The respondent's perceptions of the ability to recognize opportunities is measured by six statements., which are belief in success, the profit, actions to improve results, the speed in making decisions, finding information, and open to new ideas. 
In a statement of belief to succeed, the perception of respondents can be seen in the following table based on the results of questionnaires given to the SME culinary in Bandung Raya:

Competencies Opportunity indicator category included in the category of Appeal (3424) for obtaining a score between 20613780. Overall statement for this category has been included in the category of Appeal. This means that the opportunity for business in culinary field in Bandung Raya is good. Awareness in capturing opportunities in the field of culinary business has been rated good.

\section{Organizing Competencies (Ability to Manage Business)}

Organizing Competencies indicator is measured using five statements related Organizing Competencies, which are: used to lead others, control the operational activities of the company, develop the business, and a clear division of tasks.

Organizing Competencies indicators included into the category of Enough (1363) by obtaining a value between $1301-1700$. This means that the ability to manage efforts should be increased by SMEs of culinary in Bandung Raya.

\section{Strategic Competencies (Strategic Capabilities)}

The next indicator in small businesses competence of culinary field is Strategic Competencies (strategic capability). Strategic Competencies indicator is measured by six statements consisting of building good relationships with lots of people, always expanding the business network, information that shared with others, cooperation in achieving goals, awards and honors in gaining the loyalty of others, and use the media to influence other people.

Strategic Competencies including in the category Enough (3386) with a score of between 2061 - 3780. This means that small businesses in the culinary field of Bandung Raya have a good strategic capability.

\section{Social Competencies (Social Skills)}

Asocial Competencies or social skills indicator formed by five statements of the way it affects others, how to earn the respect of others, familiarizing yourself with others, communicate ideas, and to control the situation.

Competencies Social Indicators included in the category of Appeal (2759) because it gets a score between $2551-3150$. This means that the social capability of small businesses in the culinary field of Bandung Raya is already high. Although it still needs improvement in order to have better social skills since they are important for small businesses in the culinary field Bandung Raya

\section{Commitment Competencies (Skills in commitments)}

Next is the perception of respondents to Commitment Competencies (Skills in Commitment) indicator which is described by six statements consisting of: the responsibility of the operating results in the culinary field, the effort to do the best, to spend more time, responsibility for employment, employment conformity with the value system owners, have a passion to be an entrepreneur of culinary field. The results will be described hereinafter.

Competencies Commitment indicators included in the high category. This means that the ability of the commitment to small businesses in Bandung Raya culinary high (2825) for obtaining a score between 25513150 .

\section{Conceptual Competencies/Capabili- ties Concept}

The competence of the commitment of organization will be described hereinafter Competencies Conceptual indicator of small businesses in the culinary field of Bandung Raya. Conceptual Competencies used to measure five statements which consist of establishing the innovation of products offered, learn how to run and develop a business, communicate with consumers about products being sold, sensitivity in response to the market, and open to new ideas.

Indicator of conceptual competencies including into the category of Self (1472) since it has a score of between 1301-1700. This means that the ability of the small businesses conceptual in Bandung Raya culinary field still needs to be improved because it provides good directions in the development of the culinary business. 
Table 7

Category Variable Competencies

\begin{tabular}{|l|c|c|}
\hline \multicolumn{1}{|c|}{ STATEMENT } & CATEGORY INDICATORS & $\begin{array}{c}\text { VARIABLE } \\
\text { CATEGORIES }\end{array}$ \\
\cline { 1 - 2 } opportunity Competence & HIGH & \multirow{3}{*}{ HIGH } \\
\hline Organizing Competencies & HIGH \\
\cline { 1 - 2 } Strategy Competencies & HIGH \\
\cline { 1 - 2 } Social Competencies & HIGH & \\
\cline { 1 - 2 } Commitment Competencies & HIGH & \\
\cline { 1 - 2 } Conceptual Competencies & ENOUGH & \\
\hline
\end{tabular}

Source: Questionnaire, reprocessed 2017

Table 8

Category of Variable Business Survival

\begin{tabular}{|l|c|c|}
\hline STATEMENT & CATEGORY INDICATORS & VARIABLE CATEGORIES \\
\hline survival & Enough & Enough \\
\hline Going Concern & Enough & \\
\hline Empirical Facts & Enough & \\
\hline
\end{tabular}

Source: Questionnaire, reprocessed 2017

Furthermore, after all the indicators have been measured, the competency categories of small businesses in the culinary field Bandung Raya is obtained with the results as follows.

According to the table above, variable competence for small businesses in the field of culinary of Bandung Raya is included in the high category.

Opportunity Indicator Competencies included into the category of High (2454) for obtaining a score between2040-2520. Overall statement for this category has been included in the category of Appeal. This means that the opportunities for business in reading skills in the culinary field Bandung Raya is good. Awareness in capturing opportunities in the field of culinary business is also good.

Organizing Competencies indicators included into the category Enough (1363) for obtaining a value between $1301-1700$. This means that the ability to manage efforts should be increased by SMEs of culinary in Bandung Raya.

Competencies Strategic indicators including the category Enough (1628) with a score of between 1560 - 2040. This means that small businesses in the culinary field Bandung Raya yet have a good strategic capability.

Competencies Social Indicators included in the category of High (1878) because it gets a score between 1701-2100. This means that the social capability of small businesses in culinary field of Bandung Raya is already high. Although it still must be improved in order to have better social skills because of social skills important for small businesses in the culinary field Bandung Raya.

Competencies Commitment indicators included in the high category. This means that the ability of the commitment in small businesses of culinary in Bandung Raya is high (2574) for obtaining a score between 2040-2520.

Indicator of conceptual competencies is including into the category of Self (1472) because it has a score of between $1301-1700$. This means that the ability of the conceptual small businesses in culinary field still needs to be improved because it provides good directions in the development of the business.

\section{Respondents Perception on Business Survival}

Dimension of survival in measuring the continuity of the small businesses of culinary field is using three indicators: improvement, profitability, and market share

The following is explanation of the respondent's perception of the dimension of survival. 


\section{Going Concern}

In measuring the dimensions of a going concern, three indicators are used by investor: venture capital, venture capital assisted by creditors, and had sufficient capital to run the business.

Category dimensions of going concern is in the category Enough (1285) means that the culinary business run by small businesses in Bandung Raya enough to be able to survive in the long term.

\section{Empirical Facts}

In measuring the dimensions of empirical facts, three indicators are used: the stability of the state of the business, the competitive state of business and resistance to pressure. According to the above categories, empirical facts are in the category of Self (1316) means it is quite easy to plunge into the culinary business in Bandung Raya.

Based on the above table, the category for the dimension of going concern is in the category Enough (1285) means that the culinary business run by small businesses in Bandung Raya is enough to be able to survive in the long term. Empirical facts category is the category of Self (1116) means it is easy to plunge into the culinary business in Bandung Raya.

\section{Relationship of Competence and Continuity Business Communities}

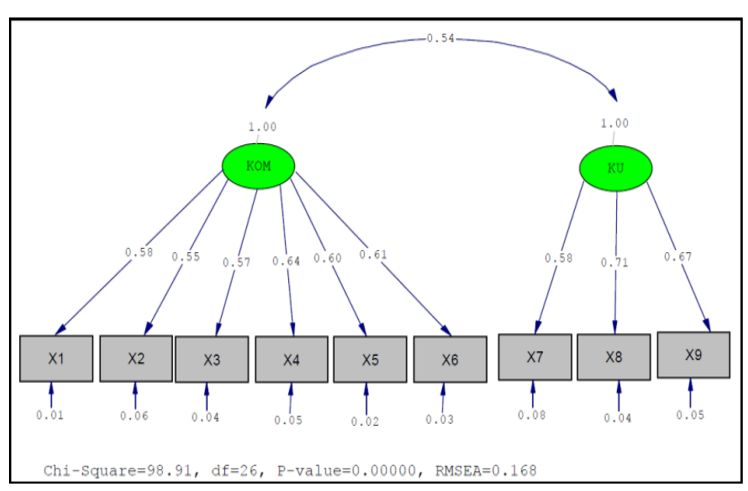

Figure 7. CFA first-order construct of Competence Business and Continuity of the Business

\section{Feasibility Model}

The above image forming indicator constructs all first order has a value of loading factor $>0.5$. It can be concluded all valid indicators. Judging from the goodness of fit model is also very good with GFI $=0.82$ value greater than 0.8 . Judging from the $p$-value $(0.0000)$ is smaller than $a=0.05$, then the model is feasibly built.

\section{Significance}

Because of $p$-value 0.0000 less than 0.05 , then there is relationship between competence and significant continuity of their business. This means that there is both competency and business survival can be used to measure each variable and do follow-up tests for the study.

\section{Confirmatory Factor Analysis of Business Communities Competence}

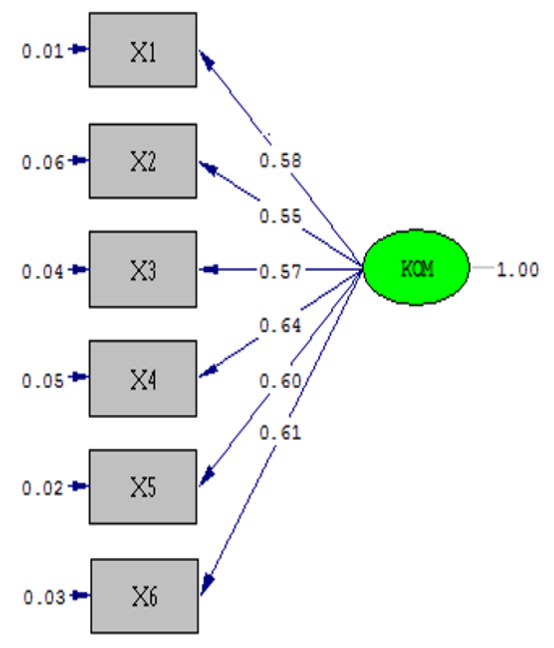

Figure 8 Confirmatory Factor Analysis of Competence

Image: Questionnaire, reprocessed 2017

Based on the picture above, the loading factor values obtained values higher than 0.6. That is the model used to measure the competence is worthy for small businesses in the culinary field Bandung Raya. Competence model based on the factor analysis: there are six dimensions that measure the competence of small businesses of culinary in Bandung Raya that can be used to measure Iatent variables.

That is the competence of small businesses has to measure factors of: Opportunity Competencies, Organizing Competencies, Strategy Competencies, Social Competencies, Commitment Competencies, Conceptual Competencies. 


\section{Confirmatory Factor Analysis of Busi- ness Survival}

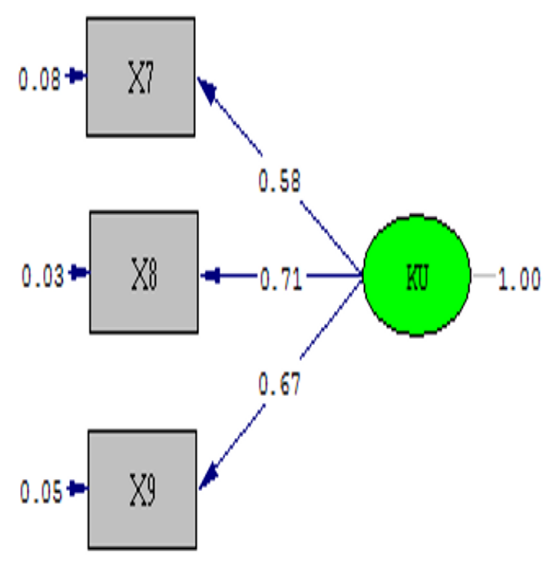

Figure 9 Confirmatory Factor Analysis of continuity of their business

Source: Questionnaire, reprocessed 2017

\section{Conclusion}

Based on the results chapter, this study can be served as following: indicator of entrepreneur competence and business survival which can be explain by all indicator that the researcher used. Small businesses of culinary in Bandung Raya have a high category for the dimension opportunity competency, organizing competency, strategy competency, social competency, and commitment competency. Although, there is still a category of sufficient dimension, that is conceptual competency. So that small business in the culinary field in Bandung Raya should pay more attention in building a business concept that can promote their business.

Business survival category is measured by dimensions of survival, going concern and the overall empirical facts which are still categorized as enough. This means that small businesses must go to be a better culinary field through elicits or maintain the continuity of their business in order to grow into a better culinary effort.

Based on the results of the factor analysis confirmatory models of good dimensions and dimensional, continuity of their business competency has a good model and each dimension can explain the latent variables. So that the competence of small businesses are related to the effort of survival.

Entrepreneur in SMEs could use dimension of opportunity competency, organizing competency, strategy competency, social competency, and commitment competency, and to get continuity in business. So with improving Entrepreneur competence, entrepreneur in culinary business can keep the business survive.

\section{References}

Banbury, C.M., Mitchell, W., (1995), The Effect of Introducing Important Incremental Innovations on Market Share and Business Survival. Strategic Management Journal 16 (Special Issue: Technological Transformation and the Competitive Landscape), 161-182

Badan Pusat Statistik. 2010. https://www. bps.go.id/dynamictable/2015/11/04/974/ indeks-produksi-triwulanan-industrimikro-dan-kecil-2010-100-menurut-2digit-kbli-2011-2017.htmlbps.go.id

Dimitriades, Zoe S, 2007. The Influence of Service Climate and Job Involvement on Customer Oriented Organization Citizenship Behavior In Greek Service Organizations: a Survey. Employee Relation Vol.29 No.5 pp 469-491 Emerald Group Publishing Limited 01425455 DOI $10.1108 / 0142545710776290$

Erävala, Kyllikki Taipale. Heilmann, Pia. Lampela, Hannele. (2014). Survival competence in Russian SMEs in a Changing Business Environment.Journal of EastWest Business, 20:25-43, 2014 ISSN: 1066-9868 print/1528-6959 online

Kaur, Hardeep. Bains, Anupama. (2013). Understanding The Concept of Entrepreneur Competency. Journal of Business Management \& Social Sciences Research (JBM\&SSR) ISSN No: 2319-5614 Volume 2, No.11, November 2013

Kessler, Robin. (2008). Competency-Based Performance Reviews: How to Perform Employee Evaluations The Fortune 500 Way. Terjemahan. Jakarta: PPM

Khalid, Saba. Bhatti, Khalid. (2015). Entrepreneurial competence in managing partnerships and partnership knowledge exchange: Impact on performance differences in export expansion stages. Journal of World Business. WORBUS-728; No. of Pages 11

Kieso, D.E., Weygandt, J.J., Warfield, T.D., (2010), Intermediate Accounting, $13^{\text {th }}$ ed. John Wiley \& Sons, Inc., New York.

Kurniawan Asep, Dwiana Elis, (2011). Keterkaitan Kompetensi Karyawan Dengan Produktivitas Kerja Karyawan. Jipolis Jurnal Ilmu Politik dan Ilmu Sosial. ISSN: 1829-6777 Vol.7 No.2 Mei 2011 
Kurniawan Asep, Irawan Andri, Yun Yun. (2016). Model Kompetensi Pelaku Usaha Kecil Bidang Kuliner di Kota Cimahi dan Kota Bandung. Laporan Penelitian Kompetitif UNJANI.

Kurniawan, Asep. Jalaludin, Agus. Hastuti, Sri. (2014). Permasalahan Kompetensi Pelaku Usaha Kecil Bidang Kuliner di Kota Bandung dan Kota Cimahi. The 7th NCFB and Doctoral Colloquium 2014. ISSN NO: $1978-6522$

Man, T.W.Y., Lau, T. and Chan, K.F. (2002). The Competitiveness of Small And Medium Enterprises: a Conceptualisation With Focus on Entrepreneurial Competencies. Journal of Business Venturing 17(2): 123-142.

Noe, Hollenbeck, Gerhart, Wright. 2006. Human Resources Management: Gaining a Competitive Advantage. Fifth edition., Irwin, New York: Mc. Graw Hill.

Okpara. John O. (2011). Factors constraining the growth and survival of SMEs in Nigeria implications for poverty alleviation. Management Research Review Vol. 34 No. 2, 2011 pp. 156-171.

Rianto, Teguh. (2015).Tantangan UKM dalam Menghadapi MEA. https://zahiraccounting. com/id/blog/tantangan-ukm-dalammenghadapi-mea/diakses Februari 2016, pukul 21.00

Rimsky K Judisseno. (2008). Jadilah Pribadi yang Kompeten di Tempat Kerja. Jakarta:
PT. Gramedia Pustaka Utama

Sakur. (2011). Kajian Faktor-Faktor yang Mendukung Pengembangan Usaha Mikro Kecil dan Menengah: Studi Kasus di Kota Surakarta. Spirit Publik. ISSN 1907-0489. Vol 7 No 2 hal 85-110.

Spencer, Lyle M. JR., \& Signe M. Spencer. (1993). Competence at Work, Models for Superior Performance. John Willey \& Sons Inc.

Sugiyono. (2017). Metode Penelitian Kuantitatif, Kualitatif, dan R\&D. Bandung: Alfabeta

Sumual, Tinneke E.M. (2015). Pengaruh Kompetensi Kepemimpinan, Budaya Organisasi terhadap Kinerja Pegawai di Universitas Negeri Manado. MIMBAR. Vol 31 , No 1 71-80.

Suryana, (2005), Kewirausahaan, Penerbit Erlangga

Sutopo, Dhanny Septimawan. (2016).Vitality of Village UMKM in The Arena of ASEAN Economic Community. MIMBAR, Vol 32 No 2 pp 412-420.

Sya'roni, Deden A.Wahab dan Sudirham, Janivita J. Kreativitas dan Inovasi penentu Kompetensi Pelaku Usaha Kecil. (2014) Bandung. Jurnal Manajemen Teknologi.

Zimmerer, Thomas $\mathrm{W}$ and Scarborough, Norman M, (2005). Essentials of Entrepreneurship and Small Business Management, Fourth Edition, Pearson Prentice Hall. 